\title{
TENTATIVE REFERENCE ACTS? 'RECOGNITIONAL DEMONSTRATIVES’ AS MEANS OF SUGGESTING MUTUAL KNOWLEDGE - OR OVERRIDING A LACK OF IT
}

\author{
MANFRED CONSTEN \\ University of Jena \\ Manfred.Consten@uni-jena.de \\ MARIA A VERINTSEVA-KLISCH \\ University of Tübingen \\ maria.averintseva@uni-tuebingen.de
}

\begin{abstract}
In an explorative study on German oral corpus data we investigate recognitional use of proximal demonstratives as a means of explicit speaker-hearer interaction shaping the discourse structure. We show that recognitionals mark tentative reference acts in that speakers suggest - or pretend - mutual knowledge of the referent, at the same time appealing to the hearers to accept the reference. Hearers may tacitly or explicitly accept the referential act or deny it asking for clarification, in the latter case making speakers change the intended local discourse topic. On these grounds we argue against a differentiation between recognitional and indefinite demonstratives, subsuming both as kinds of recognitional use under 'pretended' cognitive proximity.
\end{abstract}

\section{Recognitional demonstratives - state of research}

In our paper, we concentrate on a particular use of strong proximal demonstratives ${ }^{1}$, where referents that are neither prementioned nor accessible via the discourse situation are referred to with demonstrative NPs, like in (1):

S: dort unten konnte man den Wein richtig becherweise trinken.

$\mathrm{H}: \underline{M h h}$.

1 Proximal is meant as opposed to distal demonstratives (cf. Engl. this/these+N versus that/those $+\mathrm{N}$ ). For our study on German data, the distinction of proximal versus distal demonstrative expressions is negligible, since contrary to English, such an opposition is not expressed lexically in modern German language use. The former distal determiner and pronoun jen- sounds archaic both in deictic and anaphoric use (Himmelmann 1997: 49f) and is not suitable to constitute any opposition to the recognitional or empathic use of proximal demonstratives (with one exception mentioned in section 4, note 18). There was not one single instance of jen- in our data. 
S: Meine Eltern haben immer viel Rotwein gekauft aus diesen berüchtigten Tschian-- Chiantiflaschen, und ich [...]. ${ }^{2}$

(PF 002. Speaker: $\mathrm{m}, 16$, reporting about his trip to Italy)

"S: there you were able to drink wine tumblerfuls [intended: in large amounts].

$\mathrm{H}: \underline{\mathrm{Mhmh}}$.

S: My parents used to buy lots of red wine from these notorious Chianti bottles, and I [...]"

Such use identified for different languages (Diessel 1999, Himmelmann 1996, 1997) is called recognitional or anamnestic use. Recognitional demonstratives are analysed as means of discourse organisation: using recognitional demonstratives, speakers suggest to hearers that the respective referent is part of their private ("personalized", Himmelmann 1996) mutual knowledge and thus identifiable. At the same time speakers might anticipate problems with the referent identification and give hearers an opportunity to ask for a closer specification; the latter is taken to be the particular function of the demonstrative reference act. It has been noticed that recognitional use typically involves non-topical referents, and that recognitional reference has an emotive component (cf. Auer 1981, 1984, Diessel 1999, Himmelmann 1996, 1997, and Molnár 2010, among others).

Besides, at least for English a so-called indefinite this has been described (Ionin 2006, Maclaran 1980, Prince 1981, among others). For cases like (2), it is assumed that the referent of the this-NP is not prementioned, not present in the discourse situation and not known to the hearer, so that this serves not as a demonstrative but as an indefinite article with specific reference ${ }^{3}$ :

One day last year on a cold, clear, crisp afternoon, I saw this huge sheet of ice in the street. (Prince 1981: 232)

Von Heusinger, Chiriacescu \& Deichsel (2010) argue also for German for a similar differentiation between the proximal demonstrative dies-, including its recognitional use, and an indefinite dies-. They claim that recognitional cases allow the definite article der instead, the referent being known to the hearer although not prementioned and not present at the current discourse, while indefinite dies- alternates with an indefinite article ein, as the referent is not only not prementioned and physically absent, but also new to the hearer, cf. (3) vs. (4):

\footnotetext{
${ }^{2}$ In this paper, we use mostly data out of a transliterated German oral corpus (interviews with larger monological narration sequences, Pfeffer Corpus, cf. section 2). We change the examples only in that we make relevant marking via formatting: we use underlining for the relevant hearer's reaction, bold for the recognitional demonstrative NPs and shading for speaker's explicit appeals to the hearer.

3 Whether this 'indefinite this' is a particular use of the proximal demonstrative or the demonstrative and the indefinite are homonymous lexemes, the latter presumably as a lexicalization of the former, is controversially discussed in the literature; Ionin (2006) explicitly votes for two lexemes.
} 
(3) Was ist eigentlich mit diesem/ dem/ *einem Telefon passiert, das immer in deinem Zimmer war?

"What has actually happened to this/ the/ *a phone which used to be in your room?"

(4) Gestern kam ich in eine Bar und da war dieser/ *der Fremde/ ein Fremder, der mich die ganze Zeit anstarrte.

"Yesterday I walked into a bar and there was this/ a/ *the stranger who stared at me all the time."

(von Heusinger et al. 2010, ex. (10) and (13))

Note that the hearer-related status of the referent is taken to be unambiguously clear to the speaker. We will return to this point later (section 2.4).

In our paper, we evaluate the claims on demonstrative uses dubbed as recognitional and 'indefinite' in German on data from a German oral interview corpus and show that demonstrative uses are on the one hand much more versatile and on the other hand more systematic than has been claimed before. In particular, we show that

(i) the actual status of the referent as known to the hearer or not is not that clear as claimed in the literature (sections 2.1,2.4). That is why a distinction between recognitional and 'indefinite' dies- is empirically unsound.

(ii) the referent may be topical or not, with its (non-)topicality arising in the interaction of the speaker and the hearer: it is possible that the speaker does not intend to make a referent topical, but has to change the topic structure of the discourse segment after a corresponding request of the hearer. Similarly, the reference might co-occur with emotive emphasis, but this co-occurrence is not necessary (section 2.3).

(iii) in spite of this overwhelming diversity, recognitional demonstratives have a clear uniform function: they are discourse markers that shape explicit speakerhearer interaction. They give speakers the possibility to make a tentative reference act, i.e. to refer with insufficient linguistic means leaving open if the reference is really resolvable for the hearer and appealing to accept this deficient reference. Furthermore, they give hearers the alternative to express a tacit acceptance with respect to the establishment of the referent in the discourse world or to step in and ask for clarification (section 3 ).

Finally (section 4), we propose to integrate recognitional use into an overall concept of proximity as a discourse function expressed by demonstrativity (as proposed in Averintseva-Klisch \& Consten 2007), integrating physical proximity (situational or textual) as well as cognitive proximity, i.e. mental closeness relations between speakers and referents.

\section{Corpus findings on speaker-hearer interaction with recognitional demonstratives}

To check the assumptions on recognitional demonstratives summarized above, we did an explorative corpus pre-study, in which we have evaluated thirty interviews from a 
transcribed German oral corpus with larger monological narration sequences, the Pfeffer corpus (PF 001-030, recorded 1961, cf. Pfeffer \& Lohnes 1984) ${ }^{4}$.

Our first goal was to get an impression how prominent recognitional use of demonstratives is in our data. We consider a demonstrative use to be a clear recognitional one when (i) the referent is neither prementioned nor accessible from cotext or context and (ii) demonstrativity is not exclusively due to an empathic use. Out of overall 260 occurrences of demonstrative determiner dies $-+\mathrm{N}$, ("this $+\mathrm{N}$ ") there were 28 $(10,8 \%)$ clear recognitional uses and 12 doubtful cases (for the latter, cf. 2.3). Thus, at least for this small data segment, recognitional use seems to be rather peripheral (the most frequent use being the anaphoric one here).

Our second and more important goal was to develop refined functional categories of recognitional use and to investigate the interplay of speaker-hearer interaction, mutual knowledge of the referent identity and topicality.

\subsection{Three basic types of speaker-hearer interaction}

We actually found three types of interaction expected from the assumptions about recognitional demonstratives (esp. Auer 1981): hearers can either explicitly or implicitly accept the reference, or ask for a reference clarification.

\subsubsection{Hearers explicitly confirm a successful referring}

This option is realized in (5).

$\mathrm{H}:$ Und was macht denn nun dein Vater?

S: Mein Vati, der arbeitet auf der Elevalt-- .. also bei den Elevalt-- bei den E-Elevatoren, das ist-- sind ja diese .. Heber, nicht? Keine Landheber, sondern diese schwimmenden Heber.

$\mathrm{H}: \underline{M h m h}$.

(PF 028. Speaker: f, 22)

"H: And what does your father do?

S: My dad, he works on the elevalt..., so, at the elevalt... at the elevators, that is... they are <ja> these lifters, aren't they? No land lifters, but these swimming lifters [intended: floater cranes].

H: $\underline{\text { Mhmh". }}$

The speaker uses both the discourse particle $j a$, which marks the proposition as part of the common ground (cf. Paul 2002: 506, Zifonun, Hoffmann \& Strecker 1997: 59), and the discourse particle nicht (roughly "aren't they?") to ensure this confirmation. The

\footnotetext{
${ }^{4}$ The corpus is freely accessible via the Institut für Deutsche Sprache (IDS): http://agd.idsmannheim.de/html/dgd.shtml
} 
hearer reacts with an affirmative interjection $m h m h$ and thus explicitly accepts the reference act. ${ }^{5}$

\subsubsection{Hearers implicitly accept the reference}

If hearers do not react at all, speakers can conclude that the reference act was successful: problems would have been indicated overtly by hearers, signalling their failure and/or asking for reference clarification. In this sense, in (6) the reference is implicitly accepted:

$$
\begin{aligned}
& \text { S: Da war sehr gut besucht, weil da gar nichts los war. Da war oft bis auf den- } \\
& \text { bis auf diese .. Rabitzwand ausverkauft. Aber da war ja auch nichts in Emden } \\
& \text { (PF 026. Speaker: f, 63; an interview on theatre in Emden in the after war years) } \\
& \text { "S: It was very well-frequented, because there was nothing else going on. Often } \\
& \text { it was completely sold out up to this partition panel [Intended: Even the last } \\
& \text { tier at this wall was sold out]. Well, there was nothing else in Emden at that } \\
& \text { time." }
\end{aligned}
$$

Here, the demonstrative NP denotes a special kind of a wire plaster wall. Note that neither the lexeme Rabitzwand nor presumably the corresponding concept are known to the majority of German speakers. That is why mutual knowledge of this particular kind of partition walls is not likely; still, there are no referential problems, as no exact reference is necessary here for the intended pragmatic meaning "the theatre was sold out".

Auer (1981: 304) stresses the interactional character of the recognitional use and claims that with recognitional demonstratives hearers feel the necessity to confirm or to reject the assumed identifiability of the referent explicitly. Consequently, he does not discuss this type of examples, concentrating on cases like (5) and (7) below. However, we believe that an obvious absence of explicit interaction as in (6) should equally be seen as resulting from intentional cooperative behaviour and thus be analyzed as a kind of interaction as well.

\subsubsection{Hearers call for a reference clarification}

Sometimes hearers explicitly call for a reference clarification with a direct question about the nature of the referent like in (7). Other kinds of explicit misunderstanding signals are imaginable as well; however, in our data we have three cases of reference clarification appeals, all three being direct questions:

\footnotetext{
${ }^{5}$ The interjection $m h m h$ is admittedly a rather weak means of an explicit agreement; however, we hypothesise that the choice of a stronger means here could be interpreted as a turn claiming hearer signal (cf. Sachs, Schegloff \& Jefferson 1974), whilst $m h m h$ clearly does not have this function.
} 
(7) S: Und diese Mutzen hat man doch auch, nicht? [...] Und Berliner! [... further introductions of pastries referents].

$\mathrm{H}$ : Was sind Mutzen, muss ich noch mal fragen.

S: Das sind so... so... flaches, ausgerolltes Gebäck ist das.

(PF 039. Speaker: f, 26; speaker is talking about different local pastries)

"S: And there are those Mutzen [pl., kind of doughnuts] as well, aren't there? And Berliner [another kind of doughnuts]!

$\mathrm{H}$ : What are Mutzen, I have to inquire.

S: They are such... such... platy, rolled pastries they are."

These cases of explicit or implicit speaker-hearer interaction illustrate more or less straightforwardly the common assumptions on recognitional use. Below, some examples are discussed that do not really suit the well-described patterns.

\subsection{Problematic reference act or correct naming?}

In the data discussed in this section it is not clear whether it is really the reference that matters or the correct lexical choice: should the referent be familiar to the hearer or should the hearer confirm the lexeme used or even help at a search for a correct expression?

Thus, the speaker in (8) overtly indicates not to be sure about the correct naming for a referent she regards as identifiable:

S: Und im übrigen aßen sie zu Ostern dieses trockene Brot, Manna, heißt doch Manna, nicht? Ich weiß nicht so genau.

$\mathrm{H}:$ Ja, ja, was ist das für Zeug, kannst du das nicht mal beschreiben?

S: Ja, das war-- [laughs] das war so 'ne Art Knäckebrot.

$\mathrm{H}: \underline{M h}$.

S: Es hat an und für sich sehr gut geschmeckt, es soll ja, .. ich weiß es nicht genau, aber ich glaub, es ist ohne Gewürz, nicht?

$\mathrm{H}: \underline{M h m}$.

(PF 030. Speaker: f, 21, a German au pair talking about her English host family) "S: And besides they ate this dry bread at Easter, manna; it's named manna, isn't it? I'm not quite sure.

$\mathrm{H}$ : Yes yes, what kind of stuff is it, could you describe it?

S: Well, it was [laughs] it was a kind of crisp bread.

H: Mh.

S: Actually it tasted rather good, it is allegedly, well, I don't know, but I believe it's without spices, isn't it?

$\mathrm{H}:$ Mhmh."

The hearer first explicitly confirms that the lexical term the speaker has used is presumably correct, using twice the affirmative particle ja ja ("yes yes"), and then asks for more information about the referent.

Similarly, the speaker in (9) indicates her not being sure about the correct name for a referent she regards as identifiable: 
S: Und so wurde das s-- [stammering] vielleicht das-- der Inhalt im ganzen gewesen ist. Es wurde uns gezeigt, was die Jungens .. lernen auf den Schiffen, also eben diese Segel rauf- und runterlassen und so. Und, ach, wurde auch geschildert die großartige Gemeinschaft untereinander, [...]

(PF 009. Speaker: $\mathrm{w}, 17$, retelling a movie about a sail training ship) "S: And so it was s-- [stammering] maybe what-- the plot has been. We were shown, what the boys .. learn on the ships, well just put these sails up and down and all. And oh, the wonderful solidarity that they all had between them was also shown $[\ldots]$ ".

Here, contrary to (8), where the doubtful lexeme is a special one, the lexeme in question is a highly frequent one; presumably the speaker is not sure, whether sails is precise enough to be used here. The hearer does not react explicitly with respect to the naming.

An interesting case is (10), where the speaker fails to give the correct naming for a referent he regards as identifiable; he starts a longish sequence on clochards in Paris and the word clochard itself fails him (similar English cases of word search are discussed in Himmelmann 1996: 234):

(10) S: Erzählt wurde über das Leben, Leben von-- .. von Paris, die Menschen, über die Stadt direkt, Altertum, von Napoleon und so weiter, und von diesen, .. wie sagt man da in-- in Frankreich zu, die an'n Straßen liegen, die alten Leute, 's sind keine Bettler, es sind die wertvollsten Menschen mit. In Deutschland würde man da Bettler zu sagen, und man würde sie verachten und so weiter, aber es ist-- in Frankreich ist das umgekehrt.

$\mathrm{H}$ : Wie kommt das, daß bei uns .. .. da eine andere Auffassung herrscht?

S: Tja, wie kommt das, daß eine andere An-- Auffassung herrscht? Weil das hier in Deutschland nicht so ist wie in Frankreich. Dieses Bettler, Bettler kann man ja nicht zu sagen, die schlafen im Freien, übernachten im Freien, und so was, das gibt's in Deutschland nicht. Hier in den-- bei uns, da sitzen se, diese Bettler, die sa-- sitzen auf der Bank tagsüber rum [...]

(PF 014. Speaker: $\mathrm{m}, 47$ )

"S: We were told of the life, the life of--.. of Paris, the people, of the city as such, the antiquity, Napoleon and so on, and of these, .. how does one say it-- in France, that lay in the streets, the old people, they are not beggars, they are sort of the most valuable people at all. In Germany one would say beggars, and would despise them and so on, but it is-- in France it is the other way round.

$\mathrm{H}$ : And why do we... .. why is there a different opinion?

S: Well, why is there a different opinion? Because we don't have it the same way here in Germany and in France. This [sg. neutr.] beggars, well, beggars one cannot really say, they sleep out of doors, they spend the night out of doors, and such things, we don't have them in Germany. Here in the-- here at us, they sit there, these beggars, they sit on a bench at day [...]"

The hearer does not react at all to the word search, but does to the matter, and by joining the discussion he confirms that the referent is identifiable and thus the referring was successful. 
Diessel (1999: 107) notices that with recognitional demonstratives "the information expressed by the noun [...] may not be sufficient". As we have seen, this insufficiency is sometimes due more to naming problems, sometimes more to referent identification problems. In spite of these differences all cases discussed so far have three features in common: first, the intended referents are neither prementioned nor accessible by co-text or context. Second, speakers are not sure whether the linguistic means they use are sufficient for the intended referring. Third, the speakers initiate a negotiation with respect to the identifiability of the referent with their hearers; this negotiation can be conducted explicitly or implicitly.

In the following we consider emotive reference as a factor interplaying with a possible recognitional function.

\subsection{Recognitional or emotive use?}

Himmelmann (1997: 61) assumes a necessary emotive component with the recognitional use. However, the interplay of emotion with the recognitional use seems to be much more intricate than this assumed correlation. First, we have cases like (5), repeated here as (11), where no emotion or evaluation could be plausibly assumed:

S: Mein Vati, der arbeitet ...[] bei den E-- Elevatoren, das sind ja diese .. Heber, nicht? Keine Landheber, sondern diese schwimmenden Heber. "S: My dad, he works [...] at the elevators, they are <ja> these lifters, aren't they? No land lifters, but these swimming lifters."

In (12), demonstrative reference can be explained by emotive use alone as well, assuming that this bombing there is realized as a demonstrative NP to mark the negative attitude of the speaker towards the referent:

S: Ja, dies Grundstück hatten wir neunzehnhundertsiebenunddreißig gekauft und .. hatten auch schon ein .. Wochenendhaus drauf stehen, und wie das in Hamburg, .. diese Bomberei da losging, denn hat mein Mann hier unser kleines Wochenendhaus alles schön eingerichtet, und denn haben wir hier auch schon den Sommer über gewohnt.

H: Sah es damals schon so aus mit Gärten?

(PF 023. Speaker: w, 58)

"S: Yes, we've bought this parcel of land in 1937, and .. we already had a .. weekend cottage there, and as in Hamburg .. this bombing there started, then my husband arranged our little weekend cottage here nicely, and then we lived here the whole summer.

$\mathrm{H}$ : Was it like this with the gardens at that time already?"

Emotive reference (pejorative as well as positive) has been often described as one crosslinguistically available function of demonstrative NPs (Diessel 1999, Himmelmann 1997, among others). Emotive reference is possible to prementioned as well as to newly introduced referents, as in (13): 

a. Where is $\mathrm{John}_{1}$ ? Has anybody seen this idiot I $_{1}$ around?
b. (Holding up a dress:) Do you really want to wear this frumpy dress at the party tonight?

Here, there is nothing recognitional with the demonstrative use, (13a) being clearly anaphoric and (13b) clearly deictic. In (12), however, recognitional and emotive functions might coincide, as we can plausibly assume that the speaker could suppose the referent (the bombing of Hamburg during the Second World War) to be part of mutual knowledge.

On the contrary, the actual referent is hardly part of the mutual knowledge in (14) and (15):

$$
\begin{aligned}
& \text { S: Es war-- und dann fan-- fanda-- [stammering] war das Phantastische ja auch } \\
& \text { noch, daß diese .. Wellen, [...].. Sie hatten also diesen ganzen Wind, dieses } \\
& \text { Heulen .. dieses Windes und den--, mal diesen starken Wellengang und mal } \\
& \text { den schwachen Wellengang, den konnte man richtig hören, trotzdem wir eben } \\
& \text { im Kino saßen. }
\end{aligned}
$$

(PF 009. Speaker: w, 17, retells a movie she watched in a cinema) "S: It was-- and then fan-- [stammering] what was fantastic as well, was that these.. waves $[. .$.$] They had this whole wind, this howling .. of this wind and$ the-- at times this heavy swell, and at times the light swell, one could really hear it, although we've just been at the cinema."

S: [...] Sonst im Herbst ist es sehr schön, wenn man Rundfahrten macht. Vor allen Dingen der Südharz also ist prächtig, diese Färbung des Laubes, ganz. einzig.

(PF 001. Speaker: w, 17) "S: Then it's very nice in autumn to go on tour there. Especially is South Harz it's magnificent, this colour of the leaves, it's absolutely unique."

The hearer in (14) and (15) has hardly watched the same movie or experienced the same autumnal leaves. Here again, we could interpret the demonstrative just as a marker of a strong emotive attitude towards the referent. Still, there is a certain recognitional element here too, as the referent types, the sea waves and the autumn leaves, are very wellknown, and the identification of the referent token is actually irrelevant for understanding the speaker's meaning here, i.e. her appeal to the hearer to understand her strong feelings because similar experiences (even if with other tokens of sea or leaves) are part of the episodical knowledge of the hearer as well. ${ }^{6}$

The examples in this section show that recognitional and emotive functions do not correlate albeit they might co-occur; thus, they must not be mixed up. Still, although we argue for a differentiation of emotive and recognitional aspects, in section 4 we will propose to integrate both of them under the label of 'cognitive proximity'.

\footnotetext{
${ }^{6}$ This case shows a special kind of interplay between recognitional token reference and corresponding type reference. It would be certainly worthwhile to investigate in detail the relation of token reference to type reference with recognitionals, although this cannot be our goal in this paper.
} 
A brief look on recognitional demonstrative data has shown a greater functional diversity with respect to the reasons of the 'deficiency' of the reference act and the corresponding speaker-hearer interaction. In the next section we turn to another important feature of recognitionals in the literature, i.e. their referents being mutually known to the interlocutors. We will argue that the actual state of affairs is more complex with respect to this feature as well: referents of recognitionals are not necessarily mutually known. Still, we argue that any distinction between recognitionals and indefinite demonstratives' made on these grounds is bound to fail.

\subsection{Recognitionals vs. indefinites: a feasible distinction?}

As stated in the introduction, mutual knowledge about the referent is assumed to be essential for the recognitional use (Auer 1981, 1984, Diessel 1999, Himmelmann 1996, 1997). In particular, this feature allegedly distinguishes recognitional demonstratives from the so-called indefinite demonstratives. The referents of recognitionals are taken to be mutually known to both, the speaker and the hearer, the referents of indefinite demonstratives' on the contrary unknown to the hearer (Ionin 2006, Maclaran 1980, Prince 1981, von Heusinger et al. 2010, Ward \& Birner 1995). This referent status is the major argument for the indefiniteness of this (whereby it is not always clear, whether the underlying concept of indefiniteness is a pragmatic, a semantic or a morphosyntactic one). The main linguistic diagnostics of indefiniteness proposed in the literature are (i) the interchangeability with an indefinite article $a$ and (ii) the embeddability under locative existential there-is-construction, where this again patterns with the indefinite, cf. $(16):^{7}$

a. He kissed her with this / a / *the unbelievable passion.

(Prince 1981: 234 quoting Lakoff 1974: 347)

b. There is this / a / \#the man who lives upstairs from me who is driving me $\operatorname{mad}[\ldots]$

(Maclaran 1980: 813)

Another assumed difference between the recognitionals and the 'indefinite demonstratives' is the respective discourse prominence of the referent. The referents of recognitionals are said to be "of only peripheral importance (low topicality)" (Himmelmann 1996: 230) and consequently not to be rementioned in the subsequent discourse (Diessel 1999: 109). In contrast, the referents of 'indefinite demonstratives'

\footnotetext{
${ }^{7}$ The nature of the indefinite-definite contrast in (16) is controversially discussed in the literature: some argue that the reasons are rather syntactic or semantic ones, and that NPs grammatically marked as definites are e.g. excluded in a locative existential construction, correspondingly leading to grammaticality problems (Ionin 2006). Ward \& Birner (1995) argue convincingly against this assumption showing that grammatically definitely marked NPs can surface in this construction, as long as they obey the pragmatic constraint making reference to already identifiable referents unsuitable; cf. also Maclaran (1980). Depending on the underlying assumptions the corresponding examples are dubbed as pragmatically ill-formed or ungrammatical (original marking in (16) has been preserved).
} 
are allegedly "noteworthy" (Ionin 2006) and thus predestined to become new discourse topics after being introduced (Prince 1981, von Heusinger et al. 2010, von Heusinger 2011); von Heusinger et al. (2010: 6) even argues that otherwise a discourse is not coherent. $^{8}$

That is why in the following we consider the mutual knowledge and the topicality.

\subsubsection{Mutual Knowledge}

One point is to be made at the very beginning: we cannot, of course, talk about referents being for sure (or not) part of the speakers' and hearers' mutual knowledge; what we can do is only to hypothesise whether such knowledge could be plausibly presumed or not. Turning to the examples above, we see that mutual knowledge (at least of the referent type) is in some cases likely, as with Chianti bottles or with sails on a sailer (cf. examples (1) and (9)), or at least possible, as with swimming lifters, manna or clochards (cf. examples (5), (8) and (10)).

However, in (6) above any mutual knowledge of a particular kind of partition walls is not likely (as the word Rabitzwand has a very low frequency). Still, it should be noted that it is not possible to use an indefinite determiner here:

\section{*Da war oft bis auf eine Rabitzwand ausverkauft. \\ "*It was often completely sold out up to a partition panel."}

This suggests that the opposition "the referent is known to both speaker and hearer" as opposed to "the referent is unknown to the hearer" (the latter taken to be equivalent with indefinite use) is not that clear as suggested in the relevant literature. For instance, in the theatre example (6), it is absolutely irrelevant whether the referent (type) is familiar to the hearer or not, as the intended pragmatic meaning is "the theatre was sold out", and it can be reconstructed without resolving the reference.

Another case problematic for the mutual knowledge account is (18):

\section{S: Es war an sich nur 'n Feldweg, denn die Hauptstraßen sind in Italien schön und sehr gut, aber nicht die Nebenstraßen. Und oben dies Dörfchen auf dem Berg hieß Trimosine und hat auch einen regen .. Fernlastwagenverkehr [...] \\ (PF 002. Speaker: $\mathrm{m}, 16$, reporting about his trip to Italy) "S: Actually, it was a country lane only, because the main roads in Italy are nice and very good, but the back roads aren't. And at the top, this little village on the mountain was called Trimosine and had heavy .. traffic with long-distance trucks"}

Here it is nearly excluded that the speaker supposes that the referent could be part of the mutual knowledge: it would be very unlikely to assume that the hearer has ever been to the particular little village the speaker has visited on his holiday. Moreover, the demonstrative phrase here is the subject of a predication specifying the referent by its

\footnotetext{
${ }^{8}$ Note that the topicality-based distinction is controversial in the literature, as Auer (1981: 301) notices that with the help of recognitionals the speakers mostly introduce "new sub-themes".
} 
proper name, which can be seen as a strong grammatical indication that the referent is not expected to be known.

Even this short data review shows that the distinction between recognitional and 'indefinite' demonstratives based on the status of the referent with respect to the hearer is empirically anything but as clear as assumed in the literature. The theoretical reasons to reject the differentiation are the following:

Generally speaking, we believe that our task as pragmaticists is to explain the choice of a particular form in a particular context and its contribution to this context. Remember that following Prince (1981) an important test criterion for distinguishing between recognitional and 'indefinite' demonstratives is their interchangeability with a definite and indefinite article respectively. Seen from a pragmatic angle, however, a particular linguistic form is not really interchangeable with another. In particular, this means that in all our data indefiniteness would make a functionally clearly different contribution and thus change the pragmatic meaning of the whole utterance and its contribution to the discourse. Only with a demonstrative the speaker's referring on the one hand is explicitly marked as problematic and on the other hand appeals to the hearer to do his best to resolve the reference or at least the intended meaning. This holds as well with data where both an indefinite article (zero article in case of plural) and a definite article would be grammatical, cf. (19):

\section{Meine Eltern haben immer viel Rotwein gekauft aus den berüchtigten Chiantiflaschen / berüchtigten Chiantiflaschen (cf. ex. (1)) \\ "My parents used to buy lots of red wine from the / $\varnothing$ notorious Chianti bottles"}

The interpretation, however, differs with the choice of the determiner. With the definite article die ("the") the referent is presented as identifiable; the indefinite version has rather the reading that there is a subset of notorious Chianti bottles among other Chianti bottles. Both versions would not have the recognitional function that diese ("these") has. We thus conclude that a potential well-formedness of some other form in a given context does not really tell much about the function of the demonstrative in this context.

For these reasons and because of empirical difficulties in deciding whether the referent is really, or at least plausibly, known to the hearer or not, we propose an alternative account integrating the cases of non-anaphoric and non-deictic demonstrative use. What actually happens with recognitional demonstrative reference is that speakers (irrespective of whether any mutual knowledge is plausible) pretend mutual knowledge, acting as if there were some. In section three we will introduce the term tentative reference for this phenomenon.

Importantly, this means that even given the case one could really talk about interchanging different kinds of determiners (as we have argued above one cannot), a demonstrative-(in)definite-alternation would describe different discourse status: definite (and indefinite) articles mark the actual status of the referent in the mental discourse 
representation, while demonstrative determiners in recognitional use mark its pretended status. ${ }^{9}$

Additional evidence for our pragmatic account concentrating on the function of the demonstrative use in its context (and thus against the distinction between recognitionals and 'indefinite demonstratives') comes from the consideration of the (non)topical status of the corresponding referents.

\subsubsection{Are recognitional demonstratives discourse topics?}

We understand discourse topic in the following as the discourse referent that the speaker intends to be most stably activated in the hearer's mental representation of each discourse segment. This topic concept integrates the following notions that have been each independently proposed before, but to our knowledge have not been brought together so far:

(i) the idea of the referent a discourse segment is about (in the sense of AverintsevaKlisch 2009, Bosch \& Umbach 2007) or of a "protagonist" or "the hero of the story" (Zeevat 2004: 210);

(ii) the claim that topics are constructs crucially based on speaker-hearer interaction; as Brown \& Yule (1983: 68) put it "it's writers and hearers who have topics, and not texts";

(iii) the notion of topicality being a dynamic notion: a text will develop in different ways depending on what speakers and hearers choose as the topics for their discourse (or, taking the text as a starting point: a text has to be analysed as the result of a negotiation process between speakers and hearers).

Importantly, a discourse topic is a discourse referent (i.e. an entity at the level of the discourse representation) and not a particular expression used to refer to it. ${ }^{10}$

It has been shown for anaphoric demonstratives that they cross-linguistically tend to refer to non-topical referents, personal pronouns being predestined for the reference to topics (for German, cf. Averintseva-Klisch \& Consten 2007, Bosch \& Umbach 2007, Consten \& Schwarz-Friesel 2007, Zifonun, Hoffmann \& Strecker 1997):

Hast du schon das Neueste von unserem Chef ${ }_{1}$ gehört? Er $r_{1}$ wollte bei der Versammlung neulich Meyer 2 zu seinem ${ }_{1}$ Stellvertreter wählen lassen. $\mathbf{E r}_{1 / * 2}$ vs.

\footnotetext{
${ }^{9}$ Our discussion above is based on German data; Auer (1984: 637) claims that in German "it is not possible to use dieser in order to refer to individuals unknown to the recipient [...] whereas in English this man can imply 'you won't know him'”. For our argumentation above it is actually irrelevant, whether German has this alleged 'indefinite use' (as Heusinger et al. 2010, Heusinger 2011 argue) or not, as the theoretical considerations against postulating this 'indefinite demonstrative' (lexeme or use) on the basis of the arguments given in the literature so far would hold cross-linguistically.

${ }^{10}$ Discourse topic is to be distinguished from sentence topic in the sense of a particular expression having certain grammatic (syntactic or prosodic) as well as pragmatic features (as defined among others in Büring 1997): the crucial difference is that the former are referents and latter linguistic expressions, although there is a certain tendency to refer to discourse topics with sentence topic expressions.
} 
Dieser (Mann $)_{2 / *_{1}}$ ist aber sehr unbeliebt, weswegen der Vorschlag nicht durchkam.

"Have you heard the latest about our boss ${ }_{1}$ ? Recently, he $_{1}$ intended the meeting to elect Meyer $_{2}$ as his $\boldsymbol{h}_{1}$ deputy. However, he $\mathbf{h}_{1 / 2}$ vs. this $\operatorname{man}_{2 / *_{1}}$ is very unpopular so that the proposal did not pass."

Here, the referent ${ }_{1}$, the boss, is made discourse topic via the introductory utterance, and the demonstrative NP dieser (Mann) ("this man/ this (one)") can only refer to the nontopical referent ${ }_{2}$. This tendency to refer to non-topics has been argued to hold for recognitional demonstratives too (Himmelmann 1996, 1997).

In our data we have both cases of non-topical and topical referents. The former case is illustrated with the swimming lift example (5), repeated here as (21) with more context:

$\mathrm{H}:$ Und was macht denn nun dein Vater $_{\mathrm{DT}}$ ?

S: Mein Vati $i_{\mathrm{DT}}$, der ${ }_{\mathrm{DT}}$ arbeitet [...]bei den Elevatoren ${ }_{2}$, das sind ja diese Heber ${ }_{2}$, nicht? Keine Landheber, sondern diese schwimmenden Heber ${ }_{2}$. Da muß er $r_{\mathrm{DT}}$ aufschreiben, wenn der Dampfer kommt, wieviel Tonnen der Dampfer hat und wieviel abgeladen werden und, weiß nicht, was er $r_{\mathrm{DT}}$ sonst noch alles [...].

"H: And what does your father ${ }_{\mathrm{DT}}$ do?

S: My dad DT $_{\text {T }}$, he DT $_{\text {Dorks }[\ldots] \text { at the elevators }}$, that is... these are these lifters , $_{1}$, aren't they? No land lifters, but these swimming lifters ${ }_{1}$ [intended: floater cranes]. When a steamer comes in, he $\mathrm{DT}_{\mathrm{DT}}$ has to record how many tons of cargo it has and how many tons are offloaded, and well, I don't know whatever else he DT [has to do]."

Here, an explicit question concerning the speaker's father makes the father-referent the discourse topic in the speaker's answer; the referent stays topic after the introduction of another referent (swimming lifters) with a recognitional demonstrative.

On the contrary, in the pastries example (7), here repeated as (22), a direct intervention of the hearer leads to the discourse topical state of the respective referent:

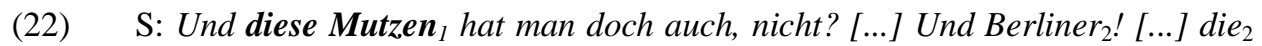
werden in Öl gebacken, nur in Öl. Das ist denn wohl zu Neujahr. [...]

$\mathrm{H}$ : Was sind Mutzen ${ }_{\mathrm{DT}}$, muß ich noch mal fragen.

S: Das ${ }_{D T}$ sind so-- so-- flaches, ausgerolltes Gebäck ist das ${ }_{D T}$. Ziemlich hart. Muß aber auch sehr frisch gegessen werden und ist denn gezuckert. So kleine Teilchen sind das ${ }_{D T}$ so, in Öl gebacken.

"S: And there are those Mutzen $_{1}$ [pl., kind of doughnuts] as well, aren't there? And Berliner ${ }_{2}$ [another kind of doughnuts]! They $y_{2}$ are fried in plant oil, only in oil. This is done at the New Year day.

$\mathrm{H}$ : What are Mutzen ${ }_{\mathrm{DT}}$, I have to inquire.

S: They ${ }_{D T}$ are such... such... platy, rolled pastries they $y_{D T}$ are. [They ${ }_{D T}$ are] rather hard. And [they $y_{\mathrm{DT}}$ ] are to be eaten as long as [they ${ }_{\mathrm{DT}}$ are] very fresh, and [they $y_{D T}$ are sugared. They ${ }_{\mathrm{DT}}$ are such little pieces, fried in oil." 
Here, Mutzen has not been intended as the sole discourse topic, "traditional festive pastries" being rather the topic. However, after an explicit request for reference clarification, the speaker starts a discourse segment featuring the Mutzen referent as its topic.

In the clochards example (10) above the clochards referent is topical without being labeled, and maybe exactly because the speaker cannot find the lexeme to label it: the lexical failure leads him to talk more about the corresponding referent to make his reference act understandable. In this case the hearer does not directly request information about the referent.

This brief data review shows the following:

(i) The referents of recognitional demonstratives may be topical or not, whereas topicality crucially depends on the hearers' reaction: irrespective of whether the referent is intended as a topic by the speaker or not, hearers can make speakers to promote the corresponding referent to the topic.

(ii) On the contrary, (non-)topicality does not necessarily correlate with lexical difficulties, nor with emotive use in any way.

These observations get us to revise the concept of the recognitional use, building on the concepts of tentative reference and negotiated topicality.

\section{Conclusions}

\subsection{Recognitional use revised: tentative reference and negotiated topicality}

On the basis of the data discussed in 2, we get a functional description of recognitional demonstratives that differs from the majority of approaches summarised in 1 above. With recognitional use, speakers leave open if their hearers really can resolve the reference: a deficiency of the reference process is made overt. This deficiency may be due to an uncertain mutual knowledge status of the referent as well as the speakers' ignorance of the exact naming for the referent, all this resulting in a failing identification of the referent. In contrast to common assumptions on the core definition of what reference is - referring as identifying a referent to the hearer (undisputed since Strawson 1950) - speakers here appeal to their hearers to accept a more or less deficient introducing with the possible result of a failing identification of the intended referent. Such an acceptance would have no negative effects on the discourse even in case of a failing identification as the referent is not that important for the ongoing discourse. In this sense, recognitional reference is tentative reference, unless it is explicitly confirmed by the hearer.

Consequently, recognitional demonstratives affect the discourse organisation at least for a larger discourse segment. Some remarks on the discourse situation in our data are required.

All of our corpus texts are interviews, mostly eliciting narrations about individual memories, and the interviewers and the speakers were not acquainted before. That means that the mental discourse world is influenced neither by external features of a speech 
situation nor by a specific mutual knowledge. ${ }^{11}$ How, then, is such a discourse world established? Our findings confirm that "the discourse situation itself has to be regarded as a social and cognitive construct that depends on the participant's activities of directing attention" (Maßß 2010:10, our transl. from German). ${ }^{12}$

This holds for the discourse organising function of recognitionals with respect to the reference act itself: recognitional use gives hearers the opportunity to interact in the establishing of referents in the discourse world. Hearers have the alternative to step in and reject the speakers' tentative reference act or to express a tacit (or explicit) acceptance.

Furthermore, recognitional use affects discourse topicality. In 2.4.2, we have rejected the claim that recognitionals are always non-topical as too undifferentiated. Indeed, such claim would be only plausible based on the assumption that hearers processing recognitionals would accept deficient reference anyway. In this case, hearers would trust in the speakers' prediction that the respective referent is of minor importance, i.e. it would not be maintained during a larger discourse segment, so a closer clarification would not be worth the communicative effort. Our data in (5), (6) and (9) match this case. There are, on the other hand, cases like (7) and (8) and (10), where the respective referent seems to be topical at least for a certain discourse segment: in (10), the topic status of the referent is evoked by the speaker spontaneously (while searching for a correct denotation). In (7) and (8), hearers require a reference clarification and thus raise the importance, that is the topicality, of the referent. In other words, recognitionals give hearers the opportunity to negotiate discourse topics, so that both speakers and hearers can actively influence the topical status of a referent.

This sketch of discourse organising functions of recognitionals has shown that the following parameters are relevant for a precise taxonomy of recognitional uses - though (ii) and (iii) have been neglected by previous research: (i) the hearers' actual knowledge (not as a criterion to distinguish between recognitionals and any 'indefinite' demonstratives, but as an explanation of the hearer's reaction, cf. (iii)!); (ii) the speakers' assumptions about and tentative models of (i); and (iii) the hearers' communicative intentions which determine acceptance or rejection of (ii). Consequently, we have to regard these hearer-related parameters as situational elements in order to achieve a proper model of the speech situation as a dynamic determinant for the ongoing discourse. If we adhere to this line of argumentation, following questions are bound to arise: is the recognitional use of demonstratives, bringing situational parameters into play, a kind of deictic use? And how to explain that proximal demonstratives fulfil such a function?

\footnotetext{
${ }^{11}$ There is, of course, a very general kind of mutual knowledge as it is shared by all members of a speech community at a certain point in time. References to these kinds of general knowledge are not covered by definitions of recognitional use as cited in 1: Himmelmann (1996: 233) states explicitly that no 'larger situation use' is possible with recognitionals, these being reserved for cases of "on specific, 'personalized' knowledge that is assumed to be shared by the communicating parties due to a common interactional history or to supposedly shared experience".

${ }^{12}$ Cf. as well Hausendorf (2003: 251), and Auer (1981), arguing generally for socio-ethological methods in linguistics.
} 


\subsection{Recognitional use - typically deictic?}

In Bühler's tradition, deictic reference is defined as reference with respect to (or pointing at) non-verbal elements of the discourse situation ${ }^{13}$. Let us argue from the assumption of a cognitive definition of 'situation' like we proposed above, i.e. a definition integrating the speakers' and the hearers' knowledge and intentions as well as their assumptions about each other's knowledge and intentions as parts of the situation. Then, two consequences arise for a deictical status of recognitionally used demonstratives: (i) They meet our notion of deixis, since speakers explicitly appeal to their assumptions about the common ground, i.e. their and the hearers' knowledge. (ii) Furthermore, recognitional use exceeds such a notion of deixis since speakers do not necessarily reflect their real assumptions of the hearers' knowledge but generate a fictitious model of it (and appeal to hearers to accept this).

Thus, recognitional use is a kind of deictic use that does not only reflect situational features but generates them ${ }^{14}$.

\section{Is there anything that demonstrative uses have in common?}

There are three discourse functions of proximal demonstratives that are frequently discussed - aside from spatial or textual deictic pointing: the marking of non-topical referents, the marking of emotive emphasis (e.g. with a pejorative evaluation of the referent) and the recognitional use. We have shown so far that these functions operate independently from each other or, at least, may co-occur or not:

For (non-)topicality, our findings suggest that (non-)topicality of referents is a matter of negotiation between discourse participants which can (though need not to) be induced by recognitional use of demonstratives (cf. 2.4 and 3.1) $)^{15}$.

Emotive use (which Himmelmann 1996 assumes to be necessarily combined with recognitional use) seems to co-occur with recognitional use in some of our corpus data (cf. 2.2.2), while in other recognitional corpus items there is no reason to assume emotive use.

\footnotetext{
${ }^{13}$ This is, roughly speaking, one of two prominent notions of deixis (esp. as opposed to anaphora, cf. Bühler 1934, Windisch 1869); the other one deals with the discourse status (new/old) indicated by deictic vs. anaphoric means (Ehlich 1982, Halliday \& Hasan 1976). For an overview of this long tradition of disputes about a sufficient notion of deixis, cf. Bosch (1983), Consten (2003, 2004), Lenz (1997).

${ }^{14}$ The latter point meets a cognitive notion of deixis as broadly discussed in Hausendorf (2003) and Mondada (2002).

15 In this paper, we argue for a dynamic interactional concept of a discourse topic using recognitional demonstratives. As mentioned above, reference to non-topics has been proposed as one of the general functions of demonstrative reference before. The underlying discourse topic definition thereby was a static concept of a referent the discourse is about (cf. among others Bosch \& Umbach 2007). Whether a dynamic interactional topic concept could be generally used to account for demonstrative vs. personal pronoun reference or not is clearly out of range of this paper.
} 
So, do we deal with an accidental conglomeration of functions related to the proximal demonstrative form, or is there any tie connecting these functions with each other and, furthermore, with spatial and textual deixis as a core function of (proximal) demonstratives? And, with respect to recognitional use, isn't it counter-intuitive that (at least in German) just proximal demonstratives serve as means to indicate a quite vague, unsettled referent status in the speakers' and hearers' discourse representation?

In previous work, we have suggested an overall concept of demonstrative reference that intends to integrate all functions discussed here (Averintseva-Klisch \& Consten 2007, Consten \& Averintseva-Klisch 2010.) Our key concept for demonstrative discourse functions is proximity, a term which we claim to be suitable for certain referent status in different reference domains:

(i) Physical proximity

is a feature indicating a close spatial relation concerning either the extra-textual or the textual domain. In case of spatial deictic pointing, physical proximity labels a small spatial distance between speakers and referents, which is the eponymous (and - therefore - a frequently mentioned) area of operation for proximal demonstratives (cf. Diessel 1999).

Our term physical proximity is extended to anaphora. Here, the text is regarded as analogous to spatial structure, so that demonstrative anaphors indicate a small distance between the anaphor and its antecedent. ${ }^{16}$ Consequently, demonstrative anaphors are preferably related to the most recent NP suitable as antecedent; in this regard demonstratives constitute an opposition to personal pronouns (cf., among others, Zifonun, Hoffmann \& Strecker 1997: 558).

(ii) Cognitive proximity

The ratio of our term cognitive proximity is to cover several instances of specific mental closeness relations between speakers and referents. The term has been created in order to state an analogy of such mental phenomena with physical proximity. Both physical and cognitive proximity are discourse functions that can be expressed by proximal demonstrative forms (though they are, of course, not limited to these forms).

With regard to emotive use (as discussed with (12)-(15)), the applicability of our notion of cognitive proximity is evident: speakers show a close emotional involvement with their topic, they express that a referent is emotionally near to them ${ }^{17}$.

As we have shown in 2.3, emotive and recognitional use occur independently (i.e. they can co-occur by chance). There is no evidence for the claim that recognitional use has an emotive component. Both are independent discourse phenomena that preferably

${ }^{16}$ Written text as a spatial 'Zeigfeld' (area of deictic pointing) and oral text as a temporal 'Zeigfeld' is a common approach to anaphora (cf. Zifonun, Hoffmann \& Strecker (1997), and especially to discourse deixis (such as: as we have argued above, as I have mentioned before), cf. Diewald (1991) and Lenz (1997). For a critical discussion and alternatives to this "localistic" approach to text structure, cf. Maaß (2010: 21-34).

${ }^{17}$ Results from a questionnaire study on German (Consten \& Averintseva-Klisch 2010) show that emotive use (a strongly negative evaluation of the referent in this case) is preferably expressed by proximal demonstratives (dies- $+\mathrm{N}$ ), at least in case that the proximity function is not at the same time expressed by the lexical meaning of the head noun (e.g.: for a referent which is introduced with pejorative cotext and unambiguously accessible, this teacher is preferred to the teacher, while this idiot and the idiot got equal preference values). 
are expressed by demonstratives - challenging an integrative model of demonstrative discourse functions. We will argue now that recognitional use can be subsumed under our notion of cognitive proximity as well ${ }^{18}$.

It seems to be anything but self-evident, however, that recognitional use is another instance of marking cognitive proximity: the respective referents are by no means near in terms of a high level of familiarity (that is why speakers are in doubt if the referents are identifiable for their hearers at all). Furthermore, the respective referents are not primarily topical - if they become topics, they do so as a result of an ongoing interaction (cf. 3.1), and there does not need to be an emotive marking (cf. 2.3).

Our findings reported in section 2 and summed up in 3.1 show the way to an explanation to what seems to be a contradiction: recognitional use is basically a tentative act of near reference. By using a referential means marking cognitive proximity, speakers pretend that the referent is part of mutual knowledge and therefore easily accessible. With recognitionals, cognitive proximity is tentatively claimed in order to evoke the hearers' reaction ${ }^{19}$. This is what makes recognitional demonstrative use a very clear-cut instance of discourse structuring means and a good reason for a consequently dynamic, interaction-based approach to the grammar-pragmatics interface.

\section{References}

Auer, Peter. 1981. “Zur Indexikalitätsmarkierenden Funktion der demonstrativen Artikelform in deutschen Konversationen". In G. Hindelang \& W. Zillig (eds.), Sprache $=$ Verstehen und Handeln (301-310). Tübingen: Niemeyer.

Auer, Peter. 1984. "Referential problems in conversation". Journal of Pragmatics, 8, 627-648.

\footnotetext{
${ }^{18}$ Alongside with emotive use and recognitional use, cognitive proximity is meant to cover:

- a short temporal distance between the time of the utterance and the time referred to (this morning "the morning of today") - a narrative construction of such a short temporal distance, i.e. a strategy of envisioning. (Only) with respect to this function, the German proximal demonstrative determiner dies- constitutes an opposition to the distal determiner jen- (in jener Nacht "in that night" narratively suggesting some "night long time ago"); cf. Consten \& Averintseva-Klisch (2010).

- in some rare cases of indirect (associative, antecedentless) anaphors with propositional textual anchors: cognitive proximity is given if the referent of the anaphor and the referent of its textual anchor are at the same epistemic level, e.g. both are real within the discourse world. Then, demonstrative anaphors are preferred or at least accepted while they seem to be dispreferred if the referent of the anaphor is real within the discourse world but anchored by a discourse part referring to something hypothetical (for examples and a close discussion cf. Averintseva-Klisch \& Consten (2007), Consten \& Averintseva-Klisch (2010)).

${ }_{19}$ Maclaran (1980) comes to the conclusion that the cases she dubs as 'indefinite' are also proximal: "The hearer is being instructed that the referent is to be found in the speaker's world, not in the shared world of speaker and hearer. This expresses proximity to the speaker" (Maclaran 1980: 817). Our analysis differs from hers in two points: first, we do not assume any predefined actual status with respect to the hearer; second, we argue that the proximity in this case is only pretended, this "acting as if" being a constitutive part of the recognitional function.
} 
Averintseva-Klisch, Maria. 2009. Rechte Satzperipherie im Diskurs. NPRechtsversetzung im Deutschen. Tübingen: Stauffenburg.

Averintseva-Klisch, Maria \& Manfred Consten. 2007. "The role of discourse topic and proximity for demonstratives in German and Russian”. In B. Behrens et al. (eds.), Special issue of Language in Contrast 7/2 (219-240). Amsterdam: Benjamins.

Bosch, Peter. 1983. Agreement and anaphora. A study of the roles of pronouns in discourse and syntax. London/N.Y.: Academic Press.

Bosch, Peter \& Carla Umbach. 2007. "Reference Determination for Demonstrative Pronouns". ZAS Papers in Linguistics, 48, 39-51.

Brown, Gillian \& George Yule. 1983. Discourse analysis. Cambridge: CUP.

Bühler, Karl. 1934. Sprachtheorie. Stuttgart: Fischer.

Büring, Daniel. 1997. The meaning of topic and focus: the 59th street bridge accent. London: Routledge.

Consten, Manfred. 2003. "Towards a unified model of domain-bound reference". In F. Lenz (ed.), Deictic conceptualization of space, time and person (223-248). Amsterdam: Benjamins.

Consten, Manfred. 2004. Anaphorisch oder deiktisch? Zu einem integrativen Modell domänengebundener Referenz. Tübingen: Niemeyer.

Consten, Manfred \& Maria Averintseva-Klisch. 2010. “'Nahe Referenten' - ein integrativer Ansatz zur Funktion demonstrativer Referenz". Sprachtheorie und germanistische Linguistik, 20/1, 1-34.

Consten, Manfred \& Monika Schwarz-Friesel. 2007. “Anapher”. In L. Hoffmann (ed.), Wortarten des Deutschen (265-292). Berlin: de Gruyter.

Diessel, Holger. 1999. Demonstratives: form, function, and grammaticalization. Amsterdam: Benjamins.

Diewald, Gabriele. 1991. Deixis und Textsorten im Deutschen. Tübingen: Niemeyer.

Ehlich, Konrad. 1982. “Anaphora and deixis: same, similar or different?”. In R. Jarvella \& W. Klein (eds.), Speech, place and action (315-339). Chichester: Wiley.

Halliday, Michael A. K. \& Ruqaiya Hasan. 1976. Cohesion in English. London: Longman.

Hausendorf, Heiko. 2003. "Deixis and speech situation revisited: the mechanism of perceived perception". In F. Lenz (ed.), Deictic conceptualization of space, time and person (249-269). Amsterdam: Benjamins.

Himmelmann, Nikolaus. 1996. "Demonstratives in narrative discourse: a taxonomy of universal uses". In B. Fox (ed.), Studies in anaphora (205-254). Amsterdam: Benjamins.

Himmelmann, Nikolaus. 1997. Deiktikon, Artikel, Nominalphrase. Zur Emergenz syntaktischer Struktur. Tübingen: Niemeyer.

Ionin, Tanya. 2006. "This is definitely specific: specificity and definiteness in article systems". Natural Language Semantics, 14, 175-234.

Lakoff, Robin. 1974. "Remarks on this and that". Chicago Linguistic Society, 10, 345356.

Lenz, Friedrich. 1997. Diskursdeixis im Englischen. Sprachtheoretische Überlegungen und lexiko-grammatische Analysen. Tübingen: Niemeyer.

Maaß, Christiane. 2010. Diskursdeixis im Französischen. Eine korpusbasierte Studie zu Semantik und Pragmatik diskursdeiktischer Verweise. Berlin et al.: de Gruyter. 
Maclaran, Rose. 1980. "On two asymmetrical uses of the demonstrative determiners in English”. Linguistics, 18, 803-820.

Molnár, Krisztina. 2010. "Anamnestische Verwendung der Demonstrativa im Deutschen und im Ungarischen". Deutsche Sprache, 4/10, 326-344.

Mondada, Lorenza. 2002. "Die Indexikalität der Referenz in der sozialen Interaktion". Zeitschrift für Literaturwissenschaft und Linguistik, 125, 79-113.

Paul, Hermann. ${ }^{10} 2002$. Deutsches Wörterbuch. Tübingen: Niemeyer.

Pfeffer, J. Alan \& Walter F.W. Lohnes (eds.) (1984). Grunddeutsch. Texte zur gesprochenen deutschen Gegenwartssprache. Tübingen: Niemeyer.

Prince, Ellen. 1981. "On the inferencing of indefinite-this NPs". In A. Joshi, B. Webber \& I. Sag (eds.), Elements of discourse understanding (231-250). Cambridge: CUP.

Sachs, Harvey, Emanuel Schegloff \& Gail Jefferson. 1974. "A simplest systematics for the organisation of turn-taking for conversation". Language, 50, 696-735.

Strawson, Peter. 1950. “On referring”. Mind, 59, 320-344.

von Heusinger, Klaus. 2011. "Specificity". In K. von Heusinger, C. Maienborn \& P. Portner (eds.), Semantics: An international handbook of natural language meaning. Berlin: de Gruyter. (Ms. under www.ilg.uni-stuttgart.de/vonHeusinger/pub).

von Heusinger, Klaus, Sofiana Chiriacescu \& Annika Deichsel. 2010. "Two specific indefinite articles in German". Handout, invited lecture at the University of Santa Cruz, California (people.ucsc.edu/ abrsvn/handout_11.pdf).

Ward, Gregory \& Betty Birner. 1995. "Definiteness and the English existential". Language, 71/4, 722-742.

Windisch, Ernst. 1869. Untersuchungen über den Ursprung des Relativpronomens in den idg. Sprachen. Leipzig: Melzer.

Zeevat, Henk. 2004. "Asher on discourse topic”. Theoretical Linguistics, 30, 203-211.

Zifonun, Gisela, Ludger Hoffmann \& Bruno Strecker. 1997. Grammatik der deutschen Sprache. Vol. 1. Berlin: de Gruyter.

\section{About the authors}

Dr. Manfred Consten works as a lecturer at the Institute for Germanic Linguistics, University of Jena. His main research area is text linguistics and reference theory, he is especially interested in text coherence, anaphora and deixis.

Dr. Maria Averintseva-Klisch is a researcher at the German Department (Deutsches Seminar) of the Tübingen University. She wrote her Ph.D. 2008 on German right dislocation and its discourse function. Her research concentrates in the first place on the discourse-grammar interface, including semantic, syntactic and pragmatic issues. 